EDITORIAL

\section{The Curse of Knowledge} Dealing With Uncertainty, as Illustrated by
the KiKK Study Results

\section{Helmut Jungermann}

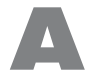
re children under 5 years of age at greater risk of developing leukemia if they live close to a nuclear power plant? And if so, how much higher is the risk?

The study by Kaatsch et al. (1) provides careful and differentiated answers to this question. Nevertheless, some readers will draw their own-varying - conclusions with regard to the risk. This although the investigation was painstakingly planned, conducted, and analyzed by an experienced and competent team, and although the data are reported lucidly and discussed critically. How can people form different opinions about the risk? How can they even argue about it?

One reason lies in the term "risk," which denotes the possibility of harm. This term is very variably defined. In automobile insurance the risk is determined by the likelihood and extent of damage, on the stock market the risk for shares is price fluctuation, and in environmental policy the loss of a species counts as a risk. In medicine the risk is expressed as the probability of disease-inasmuch as corresponding data are available. Increasingly, for instance on pharmaceutical package inserts, one finds information such as "In isolated cases ... has been observed" (2). However, many people have problems with probability. They understand it incorrectly, they overestimate low probabilities, they underestimate high probabilities (3). They fail to differentiate between low probabilities, e.g., between $10^{-2}$ and $10^{-5}$ - their perception of risk is determined purely by the possibility that something may happen (4). Moreover, an important part is played by the way in which information is presented (5). Saying that the risk of leukemia is twice as high in the 5-km zone is much more dramatic than saying that there are 0.08 more cases of leukemia per year and site than would be statistically expected. The two statements are both justified by the study data and are thus equivalent, but are likely to have a very different impact.

Even when quantitative data on probability and degrees of harm are available - and particularly when data are sparse or absent (e.g., mobile phones or genetic engineering) —other factors determine the perception and assessment of risks $(6,7,8)$. Mountaineers assess the risk of an accident lower than shown by the accident statisticsbecause they voluntarily expose themselves to the risk. Although statistics prove the opposite, flying is perceived as riskier than traveling by automobile-because plane crashes are viewed as disasters and are reported dramatically in the media. With nuclear energy, relevant factors are that radiation cannot be perceived with the senses, that the consequences of an accident are seen as appalling, and that an accident could harm future generations. These aspects likely affect the debate on the study reported here. The two core statements are: (1) The incidence of leukemia in children under 5 years old is statistically significantly higher within $5 \mathrm{~km}$ of a nuclear power plant. (2) The additional radiation exposure in this zone is 1000 times lower than the natural background radiation, so that a causal connection is implausible. Different people will assess the risk differently. Statements about risk-from lay persons or experts-always reflect individual and societal perceptions and evaluations. No interpretation is necessarily wrong. Every interpretation can legitimately be included in a discussion or decision process, but the criteria must be clearly stated (9). The fierce controversy over the study shows what emotional and political turmoil can result from different perceptions of the same findings.

The study points to problems in the estimation, assessment, and communication of risks - problems encountered ever more frequently by lay people, scientists, journalists, and politicians. It is the curse of knowledge: the more exhaustively and precisely we experiment, diagnose, measure, and analyze, the more difficult it becomes to interpret and integrate the knowledge gained.

\section{Conflict of interest statement \\ The author declares that no conflict of interest exists according to the guidelines of the International Committee of Medical Journal Editors.}

Translated from the original German by David Roseveare.

\section{REFERENCES}

1. Kaatsch P, Spix C, Junge I, Blettner M: Leukämien bei unter 5-jährgen Kindern in der Umgebung deutscher Kernkraftwerke. Dtsch Arztebl Int 2008; 105 (42): 725-32.

2. Fischer K, Jungermann $H$ : Rarely occuring headaches and rarely occuring blindness: Is rarely = rarely? Journal of Behavioral Decision Making 1996; 9: 153-72.

3. Jungermann H, Pfister H-R, Fischer K: Die Psychologie der Entscheidung. 2. Auflage. Heidelberg: Spektrum Akademischer Verlag 2005.

4. Fischer K, Jungermann H: „Zu Risiken und Nebenwirkungen fragen Sie Ihren Arzt oder Apotheker": Kommunikation von Unsicherheit im medizinischen Kontext. Zeitschrift für Gesundheitspsychologie 2003; 11: 87-98.

5. Jungermann $\mathrm{H}$ : Ethical dilemmas in risk communication. In: Messick DM, Tenbrunsel AE (eds.): Codes of conduct. Behavioral research into business ethics. New York: Russell Sage 1996: 300-17.

6. Jungermann H, Slovic P: Charakteristika individueller Risikowahrnehmung. In Bayerische Rück (eds.): Risiko ist ein Konstrukt. München: Knesebeck, 1993: 89-107.

7. Slovic P, Hg.: The perception of risk. London: Earthscan 2000.

8. Slovic P: Perception of risk from radiation. Radiation Protection Dosimetry 1996; 68: 165-80.

9. Fischhoff B, Bostrom A, Quadrel MJ: Risk perception and communication. Annual Review of Public Health 1993; 14: 183-203.

\section{Corresponding author}

Prof. Dr. phil. Helmut Jungermann

Institut für Psychologie und Arbeitswissenschaft

Technische Universität Berlin,Franklinstr. 28/29, 10587 Berlin, Germany

helmut.jungermann@tu-berlin.de

Dtsch Arztebl Int 2008; 105(42): 724

DOI: 10.3238/arztebl.2008.0724
See the article "Childhood Leukemia in the Vicinity of Nuclear Power Plants in Germany" by Kaatsch, Spix, Jung, and Blettner on the following pages 